\title{
TOXICITY STUDIES OF A DEVELOPED NEPHROPROTECTIVE POLYHERBAL FORMULATION IN EXPERIMENTAL RATS
}

\author{
SASIKALA S*, KANNIKAPARAMESWARI N
}

Department of Biochemistry, DR. N. G. P. Arts and Science College, Coimbatore, Tamil Nadu, India. Email: ss.june13@gmail.com

Received: 25 February 2019, Revised and Accepted: 27 April 2019

ABSTRACT

Objective: In the present study, acute toxicity studies were evaluated on scientifically developed nephroprotective polyherbal formulation. Polyherbal formulation consists of ethanolic extracts of dried plants of Boerhavia diffusa (BD) and Achyranthes aspera (AA).

Materials and Methods: In an acute toxicity study, polyherbal formulation was administered once orally at doses ranging from 250 mg/kg to $2000 \mathrm{mg} / \mathrm{kg}$ for 15 days. Body weight and food consumption were noted during the study period. Behavioral pattern and toxic effects were monitored in each group of animals daily. At the end of the study, blood was withdrawn for hematology and biochemical estimations. The animals were then sacrificed, and the liver, kidney, heart, and brain were dissected out which were observed for any gross morphological changes. The weights of organs were also noted.

Results: The results showed no changes in body weight, organ weight, food intake, hematological parameters, and liver function test when compared with control. The organs did not show any evidence of gross morphological changes.

Conclusion: It is concluded that developed polyherbal formulation, at a dose of $2000 \mathrm{mg} / \mathrm{kg}$, is safe for long-term treatment of kidney disorders

Keywords: Polyherbal formulation, Nephroprotective, Acute toxicity, Hematology, Biochemistry, Boerhavia diffusa and Achranthes aspera.

(C) 2019 The Authors. Published by Innovare Academic Sciences Pvt Ltd. This is an open access article under the CC BY license (http://creativecommons. org/licenses/by/4. 0/) DOI: http://dx.doi.org/10.22159/ajpcr.2019.v12i6.32805

\section{INTRODUCTION}

Plants with healing properties have long been used in different traditional medicinal systems worldwide, especially the Indian plants have been the major resource of medicines throughout the vast majority of human history [1]. The interests in medicinal plants for healing different diseases originate out of need and experience. Herbs represent as an abundant source of secondary metabolites and traditional drugs. Medicinal herbs generate various bioactive compounds that resist against any disease but possess toxic effects in nature. However, the uses of herbal medicines have been restricted by an inadequate chemical characterization, dose regimen, and required toxicity data to assess their safety. Hence, it has become important to evaluate the safety of plants used for medicinal values for possible toxicity $[2,3]$.

Kidney failure is one of the most common diseases in India. The World Health Organization identifies four major groups of renal failure, according to morphological modifications as, i) glomerular diseases, ii) tubular diseases, iii) interstitial diseases, and iv) vascular diseases. The two main types are as follows: a) acute renal failure is a syndrome characterized by prompt onset of renal dysfunction, mostly oliguria or anuria, and sudden increase in metabolic waste product in the blood and b) chronic renal failure is a syndrome characterized by progressive and irreversible degeneration of renal function due to slow destruction of renal parenchyma resulting in death. Traditional knowledge will serve as a powerful search engine and most importantly, facilitate focused and safe, natural products research to rediscover the drug discovery process. Wide variety of plants and its active principles, with minimal side effects, provides an alternate therapy for kidney diseases. Therefore, the searches of nephroprotective herbs from medicinal plants have become important and need of the day $[4,5]$. The polyherbal formulation contains two or more herbs with diverse phytoconstituents possessing similar or dissimilar curative potential have been collectively producing enviable effects during the administration of human ailments. The present research work designed to evaluate a toxic effect of novel polyherbal formulation containing extracts of selected plants (Boerhavia diffusa [BD] and Achyranthes aspera [AA]) possessing active phytoconstituents which were scientifically confirmed for the treatment of kidney diseases [6].

BD Linn. is a herbaceous plant belongs to family Nyctaginaceae. The whole plant or its specific parts (leaves, stem, and roots) are known to be an important historical, traditional medicine practicing by tribal population for long days. The medicinal property of this plant on various human diseases is mentioned in Ayurveda. Diuretic, anti-inflammatory, antioxidant activities of BD considered as therapeutic potential for the treatment of renal inflammatory diseases and complications such as ascites, nephrotic syndrome, and edema. Therefore, it is observed that $\mathrm{BD}$ ameliorates renal function and may prevent the renal cell against chemical-induced toxic effects [7].

AA Linn. (Family Amaranthaceae) is an erect stiff medicinal plant. AA possesses antimicrobial, antioxidant, diuretic, nephroprotective, wound healing, hepatoprotective, immunomodulatory, antiallergic, anticarcinogenic, antiulcerogenic, anti-inflammatory, antiarthritic, and antidiarrhea activities [8]

\section{MATERIALS AND METHODS}

The plants were procured from the Coimbatore district of Tamil Nadu, India. Authentication of plant material was carried out at the herbarium center of the Botanical Survey of India, Coimbatore, Tamil Nadu, India.

\section{Preparation of plant extract}

The fresh plant parts were washed with a running tap water and shade dried. The plant materials were crushed to coarse powder. An equal proportion of herbal formulation is subjected to successive extraction in $70 \%$ ethanol solvent by Soxhlet apparatus. The solvent of crude 
Table 1: Physical and behavioral signs of acute toxicity doses of polyherbal formulation on albino rats

\begin{tabular}{|c|c|c|c|c|c|c|c|}
\hline \multirow[t]{2}{*}{ S. No } & \multirow[t]{2}{*}{ Response } & \multicolumn{2}{|l|}{ Head } & \multicolumn{2}{|l|}{ Body } & \multicolumn{2}{|l|}{ Tail } \\
\hline & & Before & After & Before & After & Before & After \\
\hline 1 & Alertness & $\mathrm{N}$ & $\mathrm{N}$ & $\mathrm{N}$ & $\mathrm{N}$ & $\mathrm{N}$ & $\mathrm{N}$ \\
\hline 2 & Grooming & A & $\mathrm{A}$ & A & A & A & A \\
\hline 3 & Touch response & A & A & A & A & A & A \\
\hline 4 & Torch response & $\mathrm{N}$ & $\mathrm{N}$ & $\mathrm{N}$ & $\mathrm{N}$ & $\mathrm{N}$ & $\mathrm{N}$ \\
\hline 5 & Pain response & $\mathrm{N}$ & $\mathrm{N}$ & $\mathrm{N}$ & $\mathrm{N}$ & $\mathrm{N}$ & $\mathrm{N}$ \\
\hline 6 & Tremors & A & A & A & A & A & A \\
\hline 7 & Convulsion & A & $\mathrm{A}$ & A & A & A & A \\
\hline 8 & Righting reflux & $\mathrm{N}$ & $\mathrm{N}$ & $\mathrm{N}$ & $\mathrm{N}$ & $\mathrm{N}$ & $\mathrm{N}$ \\
\hline 9 & Gripping strength & $\mathrm{N}$ & $\mathrm{N}$ & $\mathrm{N}$ & $\mathrm{N}$ & $\mathrm{N}$ & $\mathrm{N}$ \\
\hline 10 & Pinna reflux & $\mathrm{P}$ & $\mathrm{P}$ & $\mathrm{P}$ & $\mathrm{P}$ & $\mathrm{P}$ & $\mathrm{P}$ \\
\hline 11 & Corneal reflux & $\mathrm{P}$ & $\mathrm{P}$ & $\mathrm{P}$ & $\mathrm{P}$ & $\mathrm{P}$ & $\mathrm{P}$ \\
\hline 12 & Writhing & A & $\mathrm{A}$ & A & A & A & A \\
\hline 13 & Pupils & $\mathrm{N}$ & $\mathrm{N}$ & $\mathrm{N}$ & $\mathrm{N}$ & $\mathrm{N}$ & $\mathrm{N}$ \\
\hline 14 & Urination & $\mathrm{N}$ & $\mathrm{N}$ & $\mathrm{N}$ & $\mathrm{N}$ & $\mathrm{N}$ & $\mathrm{N}$ \\
\hline 15 & Salivation & $\mathrm{N}$ & $\mathrm{N}$ & $\mathrm{N}$ & $\mathrm{N}$ & $\mathrm{N}$ & $\mathrm{N}$ \\
\hline 16 & Skin color & $\mathrm{N}$ & $\mathrm{N}$ & $\mathrm{N}$ & $\mathrm{N}$ & $\mathrm{N}$ & $\mathrm{N}$ \\
\hline 17 & Lachrymation & $\mathrm{N}$ & $\mathrm{N}$ & $\mathrm{N}$ & $\mathrm{N}$ & $\mathrm{N}$ & $\mathrm{N}$ \\
\hline
\end{tabular}

N: Normal, A: Absent, P: Present

extract was collected evaporated and it was stored and then it was used for further analysis [9].

\section{Experimental animals}

8-12-week-old albino rats were selected after physical and behavioral examination. The body weight range was fallen within $120-150 \mathrm{~g} \pm 20 \%$ of the mean body weight at the time of randomization and grouping. The animal purchased from M/s. Venkateshwara Enterprises Pvt. Ltd., Bangalore. The experimental procedure was approved by the Institutional Animal Ethical Committee as per the regulation of the board for the Purpose of Control and Supervision of Experiments on Animals, Ministry of Environment and Forest, Government of India (KMCRET/PhD/01/2018-19) was housed in the standard laboratory condition in polypropylene cages, provided with food and water ad libitum.

\section{Acute toxicity studies}

A preliminary study was conducted to assess acute oral toxicity of polyherbal formulation which was administered as a suspension in water. Albino rats of either sex were randomly distributed to five different groups with six animals in each group. The animals fasted overnight, and the drug was administered orally at the dose of 250, 750, 1500 , and $2000 \mathrm{mg} / \mathrm{kg}$ of body weight as a suspension in water. The animals were observed for mortality (twice daily) and clinical signs for the first 30 min after dosing and thereafter once a day for continuous 15 days. Body weight and food intake were also noted at the $1^{\text {st }}$ week and $2^{\text {nd }}$ week.

- Group I Control

- Group II polyherbal formulation $250 \mathrm{mg} / \mathrm{kg}$

- Group III polyherbal formulation $750 \mathrm{mg} / \mathrm{kg}$

- Group IV polyherbal formulation $1500 \mathrm{mg} / \mathrm{kg}$

- Group V polyherbal formulation $2000 \mathrm{mg} / \mathrm{kg}$

This study was carried out in accordance with the Organisation for Economic Co-operation and Development (OECD) guidelines for testing of chemicals, toxicity guideline no. 420 , acute oral toxicity, and fixed-dose method [10]. Blood was withdrawn at the end of the study. Hematological parameters such as hemoglobin, red blood cell count [11], white blood cell count [12], packed cell volume, differential leukocyte count, and mean corpuscular hemoglobin were estimated using the autoanalyzer [13]. Serum was separated from the blood by centrifugation, and biochemical parameters such as serum aspartate aminotransferase, serum alanine aminotransferase, and alkaline serum phosphatase [14] were estimated. The animals were then sacrificed, and the liver, heart, kidney, and brain were dissected out. The organs were weighed and were observed for any gross changes [15].
Table 2: Effects of acute toxicity doses of polyherbal formulation on body weight analysis

\begin{tabular}{lll}
\hline Groups & Initial body weight $(\mathrm{g})$ & Final body weight $(\mathrm{g})$ \\
\hline Control & $142 \pm 1.033$ & $160.7 \pm 1.606$ \\
EXT $250 \mathrm{mg} / \mathrm{kg}$ & $152 \pm 1.155^{* * *}$ & $161.8 \pm 1.493^{\mathrm{ns}}$ \\
EXT 750 mg/kg & $136 \pm 1.155^{*}$ & $148.8 \pm 1.778^{* * *}$ \\
EXT $1500 \mathrm{mg} / \mathrm{kg}$ & $154.7 \pm 1.978^{* * *}$ & $163.3 \pm 1.82^{\text {ns }}$ \\
EXT $2000 \mathrm{mg} / \mathrm{kg}$ & $153.2 \pm 1.424^{* * *}$ & $163.8 \pm 1.579^{\text {ns }}$ \\
\hline
\end{tabular}

EXT: Ethanolic extract of Boerhavia diffusa and Achyranthes aspera. Values are expressed as mean \pm SEM statistical significance (p) calculated by one-way ANOVA followed by Dunnett's $(\mathrm{n}=6)$; ${ }^{\text {ss }} \mathrm{p}>0.05,{ }^{*} \mathrm{p}<0.05,{ }^{* *} \mathrm{p}<0.01$,

${ }^{* * *} \mathrm{p}<0.001$ calculated by comparing treated groups with the control group

\section{Statistical analysis}

The data of all the parameters were analyzed using the software GraphPad Prism 5. Analysis of variance (ANOVA), one-way ANOVA followed by Dunnett's test, was performed. The values were expressed as mean \pm SEM.

\section{RESULTS}

\section{Physical and behavioral changes}

Albino rats administered with polyherbal formulation up to $2000 \mathrm{mg} / \mathrm{kg}$ did not show any kind of abnormal physical and general behavior (Table 1), during initial $4 \mathrm{~h}$ after drug administration. No mortality was observed during $24 \mathrm{~h}$ after treatment with polyherbal formulation. The normal food intake and water consumption of treated groups were found to be unaltered by the polyherbal formulation treatment as there were no significant changes in the average food intake and water consumption (data not shown) when compared with the controls.

\section{Body weight of animal groups}

The rats treated with a polyherbal formulation at the dose of $2000 \mathrm{mg} / \mathrm{kg}$ of body weights were found to grow and increase in body weight normally, and there was no treatment-related change found in the body weight gains. Table 2 shows the body weight of rats in acute toxicity study.

\section{Organ weight of animal groups}

During the study period, all the animals from all the treated dose groups showed comparable organ weight gain with that of the control group. Table 3 shows the body weight of rats in acute toxicity study.

\section{Biochemistry parameters}

The results of biochemical parameters did not show any significant change in the levels when compared with the controls. Table 4 shows the biochemical parameters of rats. 
Table 3: Effects of acute toxicity doses of polyherbal formulation on organ weights (physical parameter)

\begin{tabular}{|c|c|c|c|c|c|}
\hline \multirow[t]{2}{*}{ Groups } & \multirow[t]{2}{*}{ Liver weight (mg) } & \multicolumn{2}{|c|}{ Kidney weight (mg) } & \multirow[t]{2}{*}{ Heart weight (mg) } & \multirow[t]{2}{*}{ Lungs weight (mg) } \\
\hline & & $\mathbf{L}$ & $\mathbf{R}$ & & \\
\hline Control & $7.472 \pm 0.356$ & $0.704 \pm 0.0114$ & $0.666 \pm 0.0180$ & $0.745 \pm 0.0565$ & $1.728 \pm 0.122^{\mathrm{ns}}$ \\
\hline EXT $750 \mathrm{mg} / \mathrm{kg}$ & $7.678 \pm 0.788^{\mathrm{ns}}$ & $0.596 \pm 0.00145^{*}$ & $0.560 \pm 0.0078^{* *}$ & $0.660 \pm 0.0190$ & $1.663 \pm 0.1328^{\mathrm{ns}}$ \\
\hline EXT $1500 \mathrm{mg} / \mathrm{kg}$ & $6.721 \pm 0.241^{\mathrm{ns}}$ & $0.515 \pm 0.0018^{* * *}$ & $0.493 \pm 0.0043^{* * *}$ & $0.79 \pm 0.0517$ & $1.627 \pm 0.03301^{\mathrm{ns}}$ \\
\hline EXT $2000 \mathrm{mg} / \mathrm{kg}$ & $6.894 \pm 0.2329^{\mathrm{ns}}$ & $0.534 \pm 0.0596^{* * *}$ & $0.466 \pm 0.0064^{* * *}$ & $0.7543 \pm 0.0461$ & $1.291 \pm 0.1035^{*}$ \\
\hline
\end{tabular}

EXT: Ethanolic extract of Boerhavia diffusa and Achyranthes aspera. Values are expressed as mean \pm SEM. Statistical significance (p) calculated by one-way ANOVA

followed by Dunnett's $(\mathrm{n}=6) ;{ }^{\mathrm{ns}} \mathrm{p}>0.05,{ }^{*} \mathrm{p}<0.05,{ }^{* *} \mathrm{p}<0.01,{ }^{* * *} \mathrm{p}<0.001$ calculated by comparing treated groups with the control group

Table 4: Effect of acute toxicity doses on biochemical parameters

\begin{tabular}{llll}
\hline Group & Total bilirubin (g/dl) & SGOT (U/L) & SGPT (U/L) \\
\hline Control & $0.21 \pm 0.0289$ & $164.8 \pm 6.928$ & $56.95 \pm 2.511$ \\
EXT 250 mg/kg & $0.31 \pm 0.078^{\text {ns }}$ & $143.6 \pm 14.38$ & $44.95 \pm 4.89^{\text {ns }}$ \\
EXT $750 \mathrm{mg} / \mathrm{kg}$ & $0.34 \pm 0.0077^{\mathrm{ns}}$ & $149.3 \pm 10.68^{\text {ns }}$ & $49.45 \pm 5.225^{\mathrm{ns}}$ \\
EXT $1500 \mathrm{mg} / \mathrm{kg}$ & $0.5 \pm 0.0115^{* *}$ & $197.1 \pm 5.889^{\mathrm{ns}}$ & $139 \pm 23.38^{\mathrm{ns}}$ \\
EXT $2000 \mathrm{mg} / \mathrm{kg}$ & $0.3 \pm 0.0289^{\mathrm{ns}}$ & $135.6 \pm 4.677^{\mathrm{ns}}$ & $21.75 \pm 0.433^{\mathrm{ns}}$ \\
\hline
\end{tabular}

Oxaloacetate transaminase, SGPT: Serum glutamate pyruvate transaminase, ALP: Alkaline phosphatase. Values are expressed as mean \pm SEM Statistical significance (p) calculated by one-way ANOVA followed by Dunnett's $(\mathrm{n}=6)$; ${ }^{\mathrm{n}} \mathrm{p}>0.05,{ }^{*} \mathrm{p}<0.05,{ }^{* *} \mathrm{p}<0.01,{ }^{* * *} \mathrm{p}<0.001$ calculated by comparing treated groups with the control group

Table 5: Effect of acute toxicity doses on hematological parameters

\begin{tabular}{|c|c|c|c|c|c|c|c|c|c|}
\hline Groups & $\begin{array}{l}\text { RBC } \\
\left(\times 10^{6} / \mu \mathrm{L}\right)\end{array}$ & $\begin{array}{l}\text { WBC } \\
\left(\times 10^{3} / \mu \mathrm{L}\right)\end{array}$ & $\begin{array}{l}\mathrm{Hb} \\
(\mathrm{g} / \mathrm{dl})\end{array}$ & $\begin{array}{l}\text { Packed cell } \\
\text { volume } \\
\text { (PCV) (\%) }\end{array}$ & $\begin{array}{l}\text { Polymorphs } \\
\text { (\%) }\end{array}$ & $\begin{array}{l}\text { Lymphocytes } \\
\text { (\%) }\end{array}$ & $\begin{array}{l}\text { Monocytes } \\
\text { (\%) }\end{array}$ & $\begin{array}{l}\text { Eosinophils } \\
(\%)\end{array}$ & MCH (pg) \\
\hline Control & $4.96 \pm 0.0346$ & $14.1 \pm 0.2887$ & $12.35 \pm 0.259$ & $38.35 \pm 0.664$ & $3.5 \pm 0.866$ & $90 \pm 1.155$ & $3.5 \pm 0.2887$ & $3 \pm 0$ & $24.9 \pm 0.3464$ \\
\hline EXT & $4.68 \pm 0.092^{\text {ns }}$ & $12.45 \pm 1.93^{\mathrm{ns}}$ & $11.05 \pm 0.259^{*}$ & $34 \pm 0.9238^{*}$ & $4 \pm 0$ & $92 \pm 0$ & $2 \pm 0$ & $2 \pm 0$ & $23.65 \pm 0.0866^{\mathrm{ns}}$ \\
\hline $\begin{array}{l}250 \mathrm{mg} / \mathrm{kg} \\
\text { EXT } \\
750 \mathrm{mg} / \mathrm{kg}\end{array}$ & $5.65 \pm 0.294^{\mathrm{ns}}$ & $14.55 \pm 0.6062$ & $12.15 \pm 0.1443$ & $37.6 \pm 0.4619$ & $7.5 \pm 0.2887$ & $85 \pm 0.5774$ & $3 \pm 0$ & $4.5 \pm 0.2887$ & $23.65 \pm 0.2598^{\mathrm{ns}}$ \\
\hline $\begin{array}{l}\text { EXT } \\
1500 \mathrm{mg} / \mathrm{kg}\end{array}$ & $4.48 \pm 0.1963^{\mathrm{ns}}$ & $16.9 \pm 0.4041$ & $9.1 \pm 0.1732^{* * *}$ & $28.85 \pm 0.95^{* * *}$ & $13 \pm 0.5774^{* *}$ & $79 \pm 0.5774^{* *}$ & $4 \pm 0.5774$ & $4 \pm 0.5774$ & $20.35 \pm 0.4907^{\mathrm{ns}}$ \\
\hline $\begin{array}{l}\text { EXT } \\
2000 \mathrm{mg} / \mathrm{kg}\end{array}$ & $4.59 \pm 0.2829$ & $15.05 \pm 0.1443$ & $9.9 \pm 0.461^{* * *}$ & $30.75 \pm 1.58^{* *}$ & $11 \pm 2.887^{*}$ & $81 \pm 4.041^{*}$ & $3 \pm 0.5774$ & $5 \pm 0.5774^{*}$ & $21.65 \pm 0.3175^{\mathrm{ns}}$ \\
\hline
\end{tabular}

EXT: Ethanolic extract of Boerhavia diffusa and Achyranthes aspera, RBC: Red Blood Cell, WBC: White Blood Cell, Hb: Hemoglobin, PCV: Packed cell volume, MCH: Mean Corpuscular Hemoglobin. Values are expressed as mean \pm SEM Statistical significance $(\mathrm{p})$ calculated by one-way ANOVA followed by Dunnett's ( $\mathrm{n}=6$ ); ${ }^{\text {ns }} \mathrm{p}>0.05$ ${ }^{*} \mathrm{p}<0.05,{ }^{* *} \mathrm{p}<0.01,{ }^{* * *} \mathrm{p}<0.001$ calculated by comparing

\section{Hematology parameters}

The results of hematological parameters of the treated groups of animals did not show any significant alteration in the values when compared with the respective controls as shown in Table 5.

\section{DISCUSSION}

A variety of herbal preparations has been shown to benefit in treating kidney disease. Herbal preparations in spite of being harmless drugs need to be authenticated by different toxicity studies before being used for consumption. The safeties of the individual herbs of AA and BD are well known, but the combined effects of these herbs are unclear. Thus, it becomes essential to evaluate the safety and toxicity of the combination of these plants (BD\&AA) [16]. This preparation consists of ingredients of herbal source which has been used as kidney protective agents.

The study parameters of these studies include a comparative assessment of general appearance/behavior, morbidity/mortality, body weights, food/water consumption, laboratory analysis of hematology, and blood biochemistry in the treated and control groups of albino rats. The polyherbal formulation is a very effective compound formulation, traditionally used for the treatment of kidney diseases. Herbal products are globally used by humans and have an implicit exponential rise. However, the safety and side effects of these herbal products in the modern era are also becoming more apparent. There is a great need that regulatory policies on herbal products and medicine need to be standardized and strengthened globally [17].
Acute toxicity studies are the platform for risk detection phase of safety evaluation. As per the OECD guideline 425, the dose $2000 \mathrm{mg} / \mathrm{kg}$ body weight is assumed to be "unclassified" under the toxic range $[18,19]$. Hence, an additional study with higher doses was not performed. The acute study of polyherbal formulation up to the dose of $2000 \mathrm{mg} / \mathrm{kg}$ body weight did not show any adverse indication of toxicity, and hence, it is harmless and safe in oral formulation. There was no significant variation in the mean body weight, food intake and water consumption, and hematological and biochemical results between experimental and control groups throughout the study. This study also suggests that the LD50 value of polyherbal formulation is $>2000 \mathrm{mg} / \mathrm{kg}$ body weight of Wister rats, as all the rats survived, and there were no abnormalities in their physical and behavioral signs during the period of 14 days study.

\section{CONCLUSION}

Therefore, the present studies propose that the polyherbal formulation developed for its nephroprotective activity at the dose level of $250 \mathrm{mg} / \mathrm{kg}$ orally, daily once is safe even at a very high dose of $2000 \mathrm{mg} / \mathrm{kg}$ for treatment of nephropathy.

\section{AUTHORS' CONTRIBUTIONS}

Sasikala S designed study project and performed experiments. She was also involved in manuscript editing and experiment finalization. Kannikaparameswari $\mathrm{N}$ was a supervisor of the project. 


\section{CONFLICT OF INTEREST}

The authors declare no conflict of interest

\section{REFERENCES}

1. Dhivya JV, Santhy KS. Demystifying the ethnomedicinal plant morinda pubescens with ethnopharmacological, phytochemical, and pharmacotoxicological evidence. J Crit Rev 2018;5:1-6.

2. Subramanian K, Sankaramourthy D, Gunasekaran M. Toxicity studies related to medicinal plants. In: Natural Products and Drug Discovery. USA: Elsevier; 2018. p. 491-505.

3. Gautam MK, Goel RK. Toxicological study of Ocimum sanctum Linn leaves: Hematological, biochemical and histopathological studies. J Toxicol 2014;2014:9.

4. Nirmala RV, Abinaya R. An effect of cardioprotective activity in various medicinal plants a review. Int J Curr Pharm Sci 2019;11:1-6.

5. Talele BD, Mahajan RT, Chopda MZ, Nemade NV. Nephroprotective plants: A review. Int J Pharm Pharm Sci 2012;4:8-16.

6. Maurya H, Kumar T. Formulation, standardization, and evaluation of polyherbal dispersible tablet. Int J Appl Pharm 2019;11:158-67.

7. Pareta SK, Patra KC, Harwansh R, Kumar M, Meena KP. Protective effects of Boerhaavia diffusa against acetaminophen-induced nephrotoxicity in rats. Pharmacologyonline 2011;2:698-706.

8. Sharma VE, Chaudhary UR. An overview of indigenous knowledge of Achyranthes aspera. J Crit Rev 2015;2:7-19.

9. Santhi K, Sengottuvel R. Qualitative and quantitative phytochemical analysis of moringa concanensis nimmo. Int J Curr Microbiol Appl Sci 2016;5:633-40.

10. Organisation for Economic Co-operation and Development. Test No. 420: Acute Oral Toxicity-Fixed Dose Procedure. Paris: OECD Publishing; 2002.

11. Sood R. Textbook of Medical Laboratory Technology. $1^{\text {st }}$ ed. New Delhi: Jaypee Brothers Medical Publishers (p) Ltd.; 2007. p. 204-21.

12. John MB. Laboratory Medicine Hematology. St. Louis; CV Mosby. Co.; 1972.

13. Ghai CL. A textbook of Practical Physiology. New Delhi: JP Medical Ltd.; 2012. p. 119

14. King J. The hydrolase and alkaline phosphatase. In: Practical Clinical Enzymology. London: Nostrand Co. Ltd.; 1965. p. 191.

15. Slot C. Plasma creatinine determination. A new and specific jaffe reaction method. Scand J Clin Lab Invest 1965;17:381-7.

16. Abdulwahid SJ, Goh YM, Ebrahimi M, Mohtarrudin N, Hashim ZB. Sub-acute oral toxicity profiling of the methanolic leaf extract of clinacanthus nutans in male and female obese mice. Int J Pharm Pharm Sci 2018;10:25-35

17. World Health Organization. WHO Guidelines on Safety Monitoring of Herbal Medicines in Pharmacovigilance Systems; 2004

18. Wallace HM. Risk perception in toxicology-Part II: Toxicology must be the solution not the problem. Toxicol Sci 2011;121:7-11.

19. Dar SA, Ghazanfar K, Akbar S, Masood A, Nazir T, Siddiqui KM, et al. Acute and sub-acute oral toxicity studies of deedan-a unani drug in albino rats. J Appl Pharm Sci 2015;5:107-14. 